\title{
Comparison of Dissolved Metal Constituents of Borehole and Well Water in Osogbo Metropolis
}

\author{
By: Oparinde D.P**, Adesiyan A. A*, Adesiyan O.F^, Akiibinu M.O^^. \\ ${ }^{* *}$ Department of Chemical Pathology, Ladoke Akintola University of Technology, Ogbomosho, Osun state \\ Nigeria. \\ *Department of Biomedical Sciences Ladoke Akintola University of Technology, Ogbomosho, Osun state \\ Nigeria. \\ ${ }^{\wedge}$ Department of Chemical Pathology, Obafemi Awolowo University Teaching Hospital, lle-lfe, Nigeria. \\ ${ }^{\wedge}$ Department of Chemistry and Biochemistry, Caleb University, Lagos, Nigeria. \\ All correspondence to: aaadesiyan@lautech.edu.ng, akiibinumoses@yahoo.com
}

\section{Abstract:}

Introduction: Water is considered safe for consumption only if the dissolved particles are not hazardous to health. This study evaluated and compared the concentrations of certain metals in water from bore-holes and wells in Osogbo metropolis.

Methods: A total number of 36 boreholes and 36 wells from six different geographical zones of Osogbo were used for this study. The concentrations of calcium, magnesium, iron, manganese, copper, selenium, cobalt, cadmium, chromium, lead and zinc were determined in them using atomic absorption spectrophotometry method.

Results: Concentrations of calcium, magnesium, and manganese, increased significantly $(P<0.05)$ while the level of copper decreased significantly $(\mathrm{P}<0.05)$ in well-water when compared with bore hole-water. There were no significant differences $(P>0.05)$ observed in the levels of iron and lead in well-water when compared with bore-hole water. Zinc, cadmium, chromium, selenium and cobalt were not detected in both water samples. Levels of $\mathrm{Mg}, \mathrm{Pb}$ and $\mathrm{Cu}$ were higher in both well and bore hole waters of Osogbo metropolis when compared with the WHO standard for drinkable water.

Conclusion: It could be concluded in this study that well water may contain more dissolved metals from the top soil. To avoid metal-induced toxicity, feasibility studies may be necessary to ensure that wells are not sited in areas where toxic materials have been deposited.

Key words: Water analysis; bore-hole; well-water; metals; toxicity.

\section{Council for Innovative Research}

Peer Review Research Publishing System

\section{Journal: Journal of Advances in Chemistry}

Vol. 6, No. 3

editor@cirworld.com

www.cirworld.com, member.cirworld.com 


\section{Introduction:}

Water plays significant roles in the healthy development of man, animals and plants. It is the universal solvent that dissolves solutes including major and trace elements. Certain trace metals including $\mathrm{Al}, \mathrm{Sn}, \mathrm{Cs}, \mathrm{Cb}, \mathrm{Sr}, \mathrm{Br}, \mathrm{Cr}, \mathrm{Mo}$, $\mathrm{Co}, \mathrm{Ba}, \mathrm{Cu}, \mathrm{Zn}, \mathrm{Cd}, \mathrm{Pb}, \mathrm{Mn}$, Se, As, $\mathrm{V}$ and $\mathrm{Ni}$ have been reported in drinking and ground water samples in Southern Nigeria by Asubiojo et al. (1). Some of these elements are essential to man, but at elevated levels, morphological abnormalities such as reduced growth, increased mortality and mutation could occur $(2,3)$. The level of toxicity of a metal in water is dependent on the solubility of the metal, $\mathrm{pH}$ of the water and the presence of different types of anions or cations $(2,3)$.

One of the most important environmental issues today is ground water contamination (4). Heavy metal can cause serious health effects with varied symptoms depending on the nature and quantity of the metal ingested (5). They produce their toxicity by forming complexes with proteins, in which carboxylic acid $(-\mathrm{COOH})$, amine $(-\mathrm{NH} 2)$, and thiol $(-\mathrm{SH})$ groups are involved. These modified biological molecules lose their ability to function properly and result in the malfunction or death of the cells. The complexes formed inactivate important enzyme systems or affect protein structure. This type of toxin may also cause the formation of radicals that cause the oxidation of biological molecules. Rubenowitz et al.,(6) associated magnesium in drinking water with low mortality from myocardial infarction while calcium intake from drinking water protects against colon cancer. Different reports by Wolt (7) and Dudka et al. (8) showed that among trace elements, $\mathrm{Cd}, \mathrm{Cu}, \mathrm{Ni}, \mathrm{Pb}$ and $\mathrm{Zn}$ are common pollutant in urban industrial soil and their environmental concentration increased considerably due to human activities such as waste disposal or utilization. The concentrations of dissolved metals and other constituents depend on the sources $(9,10)$. The present study was designed to compare the concentrations of selected metals in bore-hole and well water in Osogbo, Nigeria.

\section{Materials and Methods:}

A total number of 12 borehole water and 12 well water samples were sourced from six zones ((a) OgoOluwa/Onward in Gbongan Road,(b)Odiolowo/ldiseke/Isale-Osun, (c) Powerline/llobu Road, (d) Estate/Halleluya, (e) Mercyland/Alekunwodo, (f) Owode) in Osogbo, Osun State, Nigeria. Being the capital city of Osun state, Osogbo is busy with commercial activities with few industries and a population of approximately 450,000 people,.

$20 \mathrm{ml}$ each of well and bore-hole water was taken, put into sterile universal containers and stored at $4^{0} \mathrm{C}$ in a refrigerator prior to analysis.

\section{Analytical Method:}

Determination of Trace Elements

Principle

Water trace elements were determined with flame atomic absorption spectrophotometer (AAS) using a direct method as described by Kaneko (11). The principle is based on the fact that the atoms of the element, when aspirated into the AAS, vaporized and absorbed light of the same wavelength as that emitted by the element when in the excited state. The amount of light absorbed is proportional to the concentration element in the sample.

\section{Statistical Analysis:}

All statistical analyses were performed using Statistical Package for Social Sciences (SPSS) for windows, version 15.0 (SPSS Inc. Chicago, USA). Mean, student's unpaired T-test, analysis of variance (ANOVA) were used for the comparison of means, and Pearson's correlation was used to find associations. The parameters were expressed as mean \pm standard deviation. $P$ value $<0.05$ was considered statistically significant.

\section{Results:}

Table 1 shows the mean and standard deviation of calcium, magnesium, iron, manganese, lead and copper in borehole water and well water. There were statistically significant increase in concentrations of calcium $(P<0.05)$, magnesium $(P<0.05)$, and manganese $(P<0.05)$, significant decrease in copper $(P<0.05)$, while no significant change $(P>0.05)$ were observed in iron and lead when compared with controls. Zinc, cadmium, chromium, selenium and cobalt were not detected in both water samples. Levels of $\mathrm{Mg}, \mathrm{Pb}$ and $\mathrm{Cu}$ were higher in both well and bore hole waters when compared with the WHO standard for drinkable water. 
Table 1: Comparison of trace metals in bore hole and well water.

\begin{tabular}{lllll}
\hline Parameters(mg/L) & B.H.W $(\mathrm{n}=36)$ & W.W $(\mathrm{n}=36)$ & t-value & -value \\
\hline $\mathrm{Ca}$ & $10.56 \pm 1.54$ & $11.26 \pm 1.29$ & 2.1 & $0.04^{*}$ \\
$\mathrm{Mg}$ & $1.10 \pm 0.41$ & $1.31 \pm 0.31$ & 2.5 & $0.02^{*}$ \\
$\mathrm{Fe}$ & $1.50 \pm 0.33$ & $1.62 \pm 0.27$ & 1.7 & $>0.2$ \\
$\mathrm{Mn}$ & $0.78 \pm 0.35$ & $1.11 \pm 0.47$ & 3.4 & $0.001^{*}$ \\
$\mathrm{~Pb}$ & $0.01 \pm 0.001$ & $0.02 \pm 0.01$ & 1.6 & $>0.2$ \\
$\mathrm{Cu}$ & $0.98 \pm 0.31$ & $0.70 \pm 0.55$ & 2.7 & $0.008^{*}$ \\
$\mathrm{Zn}$ & $\mathrm{ND}$ & $\mathrm{ND}$ & -- & -- \\
$\mathrm{Cd}$ & $\mathrm{ND}$ & -- & -- \\
$\mathrm{Cr}$ & $\mathrm{ND}$ & -- & -- \\
$\mathrm{Se}$ & $\mathrm{ND}$ & -- & -- \\
$\mathrm{Co}$ & $\mathrm{ND}$ & -- & - \\
\hline
\end{tabular}

B.H.W ----- Borehole water W.W ------ Well water $\mathrm{N}$----- No of samples ND ----- Not detectable

Table 2: Comparison of trace metal contents of bore hole and well water with WHO (WHO, 1998.) standard for drinkable water.

\begin{tabular}{llll}
\hline $\begin{array}{l}\text { Element } \\
(\mathrm{mg} / \mathrm{L})\end{array}$ & B.H.W $(\mathrm{n}=36)$ & W.W $(\mathrm{n}=36)$ & WHO \\
\hline $\mathrm{Ca}$ & $10.56 \pm 0.54$ & $11.26 \pm 1.29$ & -- \\
$\mathrm{Mg}$ & $1.10 \pm 0.41$ & $1.31 \pm 0.31$ & -- \\
$\mathrm{Fe}$ & $1.50 \pm 0.33$ & $1.62 \pm 0.27$ & $\begin{array}{l}\text { No limit } \\
\text { listed }\end{array}$ \\
$\mathrm{Mn}$ & $0.78 \pm 0.35$ & $1.11 \pm 0.47$ & 0.4 \\
$\mathrm{~Pb}$ & $0.01 \pm 0.001$ & $0.02 \pm 0.01$ & 0.001 \\
$\mathrm{Cu}$ & $0.98 \pm 0.31$ & $0.70 \pm 0.55$ & 2 \\
$\mathrm{Zn}$ & $\mathrm{ND}$ & $\mathrm{ND}$ & $\begin{array}{l}\text { No limit } \\
\text { listed }\end{array}$ \\
$\mathrm{Cd}$ & $\mathrm{ND}$ & $\mathrm{ND}$ & 0.003 \\
$\mathrm{Cr}$ & $\mathrm{ND}$ & $\mathrm{ND}$ & 0.05 \\
$\mathrm{Se}$ & $\mathrm{ND}$ & $\mathrm{ND}$ & 0.01 \\
$\mathrm{Co}$ & $\mathrm{ND}$ & $\mathrm{ND}$ & -- \\
\hline
\end{tabular}

WHO- -----world health organization .

B.H.W ----- Borehole water

W.W ------ Well water

$\mathrm{N}$----- No of samples 


\section{Discussion:}

Bore holes and wells are sources of water that have different depths from the earth surface, with their soil compositions and the water different in terms of dissolved organic and inorganic constituents. Abulude et al. (12) determined physicochemical properties of different water samples in Akure, Nigeria. Their results indicated that low variation existed among some physico-chemical parameters (i.e. pH, temperature, conductivity, dissolved oxygen and nitrate) and metal contents in the water samples. The variations observed were associated with various factors such as trace metal contents of all soil and crops, geographical location, fertilizers and fungicides applied in the area, environmental pollutions due to automobile emission, industrial effects, other agricultural activities and weathering of rocks. The result obtained from our study showed significant differences in the levels of certain metals detectable in the bore holes and well water. The mean levels of $\mathrm{Ca}, \mathrm{Mn}$ and $\mathrm{Mg}$ increased significantly in well water, while there were no significant changes in the levels of $\mathrm{Fe}$ and $\mathrm{Pb}$ when compared with bore hole water. This could be associated with pollution from point sources (i.e. effluent from industrial waste) and non-point sources (i.e. littering, run-off water and agricultural sources). It could be hypothesized that the nearness of the depth of well water to the dissolvable elemental top soil materials contributes to higher levels of metals in observed in it. This agrees with Olga and Alicia (13) who reported that Mn decreases in concentration with $60 \mathrm{~cm}$ depth from the earth surface. The significantly higher levels of $\mathrm{Ca}$ and $\mathrm{Mg}$ in the well water might also be due to environmental pollution from agricultural and industrial materials; which conforms to the report of Nduka and Orisakwe (14) that heavy metals and other pollutants are low in the borehole water when compared with well water. Nduka and Orisakwe, (14) also reported that bore-hole water is more acidic with less of basic metals and has higher conductivity. Previous studies show that heavy metals and other pollutants are low in the borehole water when compared with well water (14). An earlier report by Abulude et al. (12) show increased calcium concentration and significantly lower levels of manganese, cadmium, lead and chromium in borehole water. The results support the use of bore hole water as lead is recognized for centuries as a cumulative general metabolic poison (5). It is a neurotoxin and is responsible for the most common type of human metal toxicosis (15). Also, studies have linked lead exposures even at low levels with an increase in blood pressure (16) as well as with reduced intelligence quotient in children (17) and with attention disorders (18).

$\mathrm{Zn}, \mathrm{Co}, \mathrm{Se}, \mathrm{Cr}$ and $\mathrm{Cd}$ were not detectable in bore hole and well waters in Osogbo metropolis. A similar study by Abulude et al. (12) also show no detectable levels of cobalt and zinc metals in various water samples in Akure, Ondo State, Nigeria. Also, in the analysis of the water samples collected for Cadmium, 30 of the collected water samples did not contain detectable levels of Cadmium (19). It could be assumed in this study that certain metals and their salts decrease with depth from the earth surface or are bound by other materials in the surface soil. When the mean concentrations of the metals were compared with the WHO standards, $\mathrm{Mn}, \mathrm{Cu}$ and $\mathrm{Pb}$ had higher levels in both the bore hole and well water from Osogbo. Improper waste disposal might account for higher levels of $\mathrm{Pb}$ above the WHO standard in the bore hole and well water used for this study. This is an indication that certain metals can be found even at borehole depth. This study suggest that significant toxicity is imminent in populations that depend on hand dug wells and bore holes sited in areas where toxic materials are deposited.

It could be concluded in this study that hand dug wells and bore holes may contain some dissolved metals from the top soil. To avoid metal-induced toxicity, feasibility studies may be necessary to ensure that wells are not sited in areas where toxic materials have been deposited.

\section{Competing interests:}

The authors declared that they have no competing interests.

\section{Authors' contributions:}

ODP and AAA designed the study; AMO, AAA and AOF did the analysis, All authors prepared and approved the final manuscript.

\section{References:}

1. Asubiojo O.I.,Nkono N.A.,OgunsuaA.O.,OluwoleA.F.,Ward N.I. and Akanle O.A.(1997). Trace elements in drinking and groundwater samples in Southern Nigeria. Science of The Total Environment. Volume 208, Issues 1-2, Pages18.

2. Adeyeye E.I. and Abulude F.O. (2004). Analytical assessments of some surface and ground water resources in Ile-Ife, Nigeria. J. Chem. Soc. Nig. 29: 98-103

3. Asaolu S.S (2002) : Determination of some heavy metals in Orechromisnicoticus, Clariasgariepinus and Synontis spp. from the coastal water of Ondo State, Nigeria. Pak. J. Sci. Ind. Res. 45:17-19.

4. Vodela, J.K., J.A. Renden, S.D. Lenz, W.H. Mchel Henney and B.W. Kemppainen (1997). Drinking water contaminants. Poult. Sci., 76: 1474-1492.

5. Adepoju-Bello, A.A. and O.M. Alabi, (2005). Heavy metals: A review. The Nig. J. Pharm., 37: 41-45.

6. Rubenowitz E., Molin I., Axelsson G., Rylander R. (2000). Magnesium in drinking water in relation to morbidity and mortality from acute myocardial infarction. Epidemiology; 11 (4):416-21 
7. Wolt, J. (1994). Soil solution chemistry: applications to environmental science and agriculture, John Wiley \& Sons, New York.

8. Dudka, S., Ponce-Hernandez, R., Tate, G., Hutchinson, T.C. (1996). Forms of Cu, Ni and Zn in soils of Subdury, Ontario and the metal concentrations in plants. Water, Air and Soil Pollution, 90, 531-542.

9. World Health Organization (1998). Guidelines for drinking water quality, 2nd edition. Geneva. World Health Organization.

10. Obodo G.A. (2004). The bioaccumulation of heavy metals in fish from the lower reaches of River Niger. J. Chem. Soc. Nigeria. 27:173-176.

11. Kaneko J.J (1999). Clinical Biochemistry of Animal. $4^{\text {th }}$ Edition.Academic Press Inc. P 932.

12. Abulude S,O. Obidiran G.O, Orungbemi S. (2007) Determination of Physicochemical Parameter and Trace Metal Content of Drinking Water Samples in Akure, Nigeria. Elect J. Env., Agric and Food Chem.; 6 (8): 2297-2303.

13.Olga Susuna Heredia and Alicia Fernandez Cirelli (2009). Trace elements distribution in soil, pore water and groundwater in Buenos AIRES, Argentina. Geoderma. Volume 149, Issues 3 - 4, pages 409 - 414.

14. Nduka J.K.C and Orisakwe O.E. (2007). Heavy Metal Levels and Physico-Chemical Quality of Potable Water Supply in Warri, Nigeria. Chem Sus Chem. 97; 9: 867-874.

15. Berman, E. (1980). Toxic Metals and Their Analysis. Philadelphia, PA: Hayden and Sons.

16. Zietz, B.P., J. Lap and R. Suchenwirth, (2007). Assessment and management of tap water Lead contamination in Lower Saxon, Germany. Int. J. Environ. Health Res., 17 (6): 407-418.

17. Needleman, H.L. (1993). The current status of childhood low-level lead toxicity. Neurotoxicology, 14: 161-166.

18. Yule, W. and M. Rutter, (1985). Effect on Children's Behavior and Cognitive Performance: A Critical Review. In: Dietary and Environmental Lead (Pb):Human Health Effects. R. Mahaffey, (Ed.). New York: Elsevier, pp: 211-251.

19. M.A. Momodu and C.A. Anyakora. (2010) Heavy Metal Contamination of Ground Water: The Surulere Case Study. Research Journal Environmental and Earth Sciences 2(1): 39-43. 